\title{
Anticoagulant Agent
}

National Cancer Institute

\section{Source}

National Cancer Institute. Anticoagulant Agent. NCI Thesaurus. Code C263.

Any agent capable of preventing blood clot formation. 